\title{
Formulation and Evaluation of Floating and Mucoadhesive Tablets Containing Rosiglitazone
}

\author{
Jagdish K Arun' ${ }^{1}$ Dharmajit Pattanayak*1, Ramesh Adepu², C.M Hossain ${ }^{3}$, B. Shrivastava1, Ramya Sri Sura ${ }^{4}$ \\ 1. School of Pharmaceutical Sciences, Jaipur National University, Jaipur, Rajasthan \\ 2. Vikas College of Pharmaceutical Sciences, Rayanigudem, Suryapet, TS \\ 3. Bengal School of Technology, Sugandha, Hooghly, WB \\ 4. University College of Technology, Osmania University, Hyderabad, TS
}

\begin{abstract}
In this present study, floating mucoadhesive tablets of Rosiglitazone were formulated to improve the gastric retention time and overall bioavailability. Different mucoadhesive polymers like HPMC K200 M, Na CMC, Carbopol 974P, Karaya gum, Chitosan and Xanthan gum were selected to formulate the tablets. Various formulations were prepared by using these polymers in different concentration. The pre-compression blend of Rosiglitazone mucoadhesive tablets were characterized with respect to angle of repose, bulk density, tapped density, carr's index and hausner's ratio and all the results indicated that the blend was having good flow property and hence better compression properties. The swelling studies were performed for the formulations and the results depicted that all the formulations have a good swelling index. The drug release studies depicted that the formulations release the drug in first order. So based on the results, formulation RF13 was found to be an optimized formulation.
\end{abstract}

Keywords: Mucoadhesive tablets, Rosiglitazone, Bioadhesive polymers.

Article Info: Received 17 June 2019; $\quad$ Review Completed 19 July 2019; $\quad$ Accepted 26 July 2019; Available online 15 August 2019

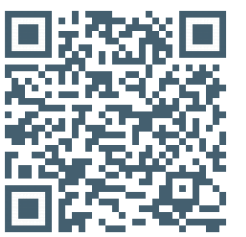

Cite this article as:

Arun JK, Pattanayak D, Adepu R, Hossain CM, Shrivastava B, Sura RS, Formulation and Evaluation of Floating and Mucoadhesive Tablets Containing Rosiglitazone, Journal of Drug Delivery and Therapeutics. 2019; 9(4-s):145-154 http://dx.doi.org/10.22270/jddt.v9i4-s.3267

Dharmajit Pattanayak, School of Pharmaceutical Sciences, Jaipur National University, Jaipur, Rajasthan, India

\section{INTRODUCTION:}

Oral route is considered to be the most safest and convenient route of drug delivery. $90 \%$ of the drug available is designed to be given through the oral route due to patient acceptance. In conventional oral drug delivery, the drug resides for a shorter period time in absorption window, so bioavailability is less. Oral controlled drug delivery systems represent the most popular form of controlled drug delivery. This type of drug delivery systems releases the drug with constant or variable release rates to meet the drug regime. [1-3]

The most preferable approach of oral controlled drug delivery is gastroretentive drug delivery systems (GRDDS), in which the dosage form retains in stomach for prolonged period increasing the Gastric residence time (GRT). GRDDS can be defined as a system which retains in the stomach for a sufficient period of time and releasing the active moiety in a controlled manner. [4] Over the last two decades, numbers of GRDDS have been designed to prolong GRT. The main aim of preparing GRDDS is to minimize the problem associated with existing oral sustained release dosage form and to develop patient benefited drug delivery. [5-7]

So the present work is designed with antidiabetic drug, Rosiglitazone with different type of controlled release and mucoadhesive polymers with different concentration to optimize a formulation which will help to overcome the above problem.

\section{MATERIAL AND METHODS:}

The antidibetic drug Rosiglitazone is obtained from the authorized supplier with the certification of purity. Apart from the drug remaining polymers like Hydroxy Propyle Methyl Cellulose K 200M , sodium carboxy methyl cellulose, Carbopol 974P, Karaya gum, Chitosan, Xanthan gum and other reaming excipients like sodium bicarbonate, magnesium stearate, talc, lactose too were obtained from authorized supplier. All the excipients and reagents used were of laboratory grade. 
Pre-compressional evaluations [6-8]

\section{Solubility Studies}

The solubility of Rosiglitazone, in $0.1 \mathrm{~N} \mathrm{HCl}$ at $\mathrm{pH} 1.2$ was determined by phase equilibrium method. An excess amount of drug was taken into $20 \mathrm{~mL}$ vials containing $10 \mathrm{~mL}$ of $0.1 \mathrm{~N}$ HCL ( $\mathrm{pH}$ 1.2). Vials were closed with rubber caps and constantly agitated at room temperature for $24 \mathrm{hrs}$ using rotary shaker. After $24 \mathrm{hrs}$, the solution was filtered through $0.2 \mu \mathrm{m}$ Whatmann's filter paper. The amount of drug solubilized was then estimated by measuring the absorbance at $248 \mathrm{~nm}$ using a UV spectrophotometer.

The standard curves for Rosiglitazone was established in 0.1 $\mathrm{N} \mathrm{HCl}$ and from the slope of the straight line the solubility of Rosiglitazone was calculated. The studies were repeated in triplicate $(n=3)$, and mean was calculated.

\section{Drug-excipient compatibility studies}

\section{Fourier transform infra-red spectroscopic studies:}

A Fourier transform - infra red spectrophotometer was used to study the non-thermal analysis of drug-excipient (binary mixture of drug: excipient 1:1 ratio) compatibility. The spectrum of each sample was recorded over the 450-4000 $\mathrm{cm}^{-1}$. Pure drug of Rosiglitazone with physical mixture (excipients) compatibility studies were performed.

\section{Pre-compression Evaluation:}

Before formulating the drug substances into a dosage form, it is essential that drug polymer should be chemically and physically characterized. Preformulation studies gives the information needed to design the dosage form and provide a framework for the drug combination with pharmaceutical excipients in the manufacture of a dosage form.

\section{Powder flow properties}

\section{Angle of repose}

Angle of repose was determined by using funnel method. The frictional forces in the lose powder can be measured by Angle of repose. The tangent of Angle of repose is equal to the coefficient friction between the particles.

$$
\theta=\tan ^{-1}(\mathrm{~h} / \mathrm{r})
$$

Where, $\theta$ is the angle of repose, $h$ is the height in $\mathrm{cm}$ and $r$ is the radius in $\mathrm{cm}$.

\section{Compressibility index}

It is an important measure that can be obtained from the bulk and tapped densities. A material having values less than 20 to $30 \%$ is defined as the free flowing material, based on the apparent bulk density and tapped density, the percentage compressibility of the bulk drug was determined by using the following formula.

$$
\mathrm{I}=\left(\mathrm{D}_{\mathrm{T}}-\mathrm{D}_{\mathrm{b}} / \mathrm{D}_{\mathrm{T}}\right) 100
$$

Where, I is the Compressibility index, Dt is the tapped density of the powder and $D_{b}$ is the bulk density of the powder.

\section{Hausner's ratio}

It indicates the flow properties of the powder and is measured by the ratio of tapped density to the bulk density

$\mathrm{H}=\mathrm{D}_{\mathrm{t}} / \mathrm{D}_{\mathrm{b}}$

Where, $\mathrm{H}$ is the Hausner's ratio Dt is the tapped density of the powder and $\mathrm{Db}$ is the bulk density of the powder.

\section{Preparation of Floating mucoadhesive tablets: [9]}

Floating mucoadhesive tablets containing Rosiglitazone were prepared by direct compression method. Various batches were prepared by changing the ratio of HPMC K200 M, NaCMC, Carbopol 974P, Karaya gum, Chitosan, Xanthan gum, NaHCO3, Talc, Magnesium stearate, Lactose. The drug and polymer mixture was prepared by homogeneously mixing the drug with HPMC K200 M, Na CMC, Carbopol 974P, Karaya gum, Chitosan, Xanthan gum, (Floating mucoadhesive polymers), Lactose in a glass mortar for 15 minutes. The Direct compressible powder is lubricated with talc and Magnesium Stearate for 2 minutes in Poly ethylene bag. The mixture $(100 \mathrm{mg})$ was then compressed using a $6 \mathrm{~mm}$ diameter die in a 9-station rotary punching machine (Lab Press, India). The details of the formulation are mentioned in table no. 1. The different formulations were evaluated further for various post compression parameters. 
Table No. 1: The Composition of Floating Mucoadhesive Tablets Of Rosiglitazone

\begin{tabular}{|c|c|c|c|c|c|c|c|c|c|c|c|c|c|c|c|c|c|c|}
\hline 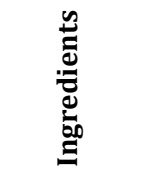 & 돈 & $\underset{\substack{N\\
}}{N}$ & $m$ & $\frac{+}{x}$ & L & $\begin{array}{l}0 \\
0 \\
0\end{array}$ & 昰 & 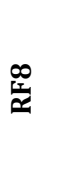 & 呑 & 옴 & $\frac{\sqrt{2}}{2}$ & $\underset{N}{N}$ & $\frac{m}{x}$ & $\underset{⿱ 亠 䒑}{\Delta}$ & L & $\underset{1}{0}$ & 돈 & $\underset{\substack{1\\
}}{\infty}$ \\
\hline $\begin{array}{c}\text { Rosiglitazo } \\
\text { ne }\end{array}$ & 4 & 4 & 4 & 4 & 4 & 4 & 4 & 4 & 4 & 4 & 4 & 4 & 4 & 4 & 4 & 4 & 4 & 4 \\
\hline $\begin{array}{c}\text { HPMC } \\
\text { K200 M }\end{array}$ & 4 & 8 & 12 & - & - & - & - & - & - & - & - & - & - & - & - & - & - & - \\
\hline $\mathrm{Na} C M C$ & - & - & - & 4 & 8 & 12 & - & - & - & - & - & - & - & - & - & - & - & - \\
\hline $\begin{array}{c}\text { Carbopol } \\
974 \mathrm{P}\end{array}$ & - & - & - & - & - & - & 4 & 8 & 12 & - & - & - & - & - & - & - & - & - \\
\hline $\begin{array}{l}\text { Karaya } \\
\text { gum }\end{array}$ & - & - & - & - & - & - & - & - & - & 4 & 8 & 12 & - & - & - & - & - & - \\
\hline Chitosan & - & - & - & - & - & - & - & - & - & - & - & - & 4 & 8 & 12 & - & - & - \\
\hline $\begin{array}{l}\text { Xanthan } \\
\text { gum }\end{array}$ & - & - & - & - & - & - & - & - & - & - & - & - & - & - & - & 4 & 8 & 12 \\
\hline $\mathrm{NaHCO} 3$ & 10 & 10 & 10 & 10 & 10 & 10 & 10 & 10 & 10 & 10 & 10 & 10 & 10 & 10 & 10 & 10 & 10 & 10 \\
\hline $\begin{array}{c}\text { Magnesiiun } \\
\text { stearate }\end{array}$ & 4 & 4 & 4 & 4 & 4 & 4 & 4 & 4 & 4 & 4 & 4 & 4 & 4 & 4 & 4 & 4 & 4 & 4 \\
\hline Talc & 3 & 3 & 3 & 3 & 3 & 3 & 3 & 3 & 3 & 3 & 3 & 3 & 3 & 3 & 3 & 3 & 3 & 3 \\
\hline Lactose & 75 & 71 & 67 & 75 & 71 & 67 & 75 & 71 & 67 & 75 & 71 & 67 & 75 & 71 & 67 & 75 & 71 & 67 \\
\hline $\begin{array}{c}\text { Total } \\
\text { Weight }\end{array}$ & 100 & 100 & 100 & 100 & 100 & 100 & 100 & 100 & 100 & 100 & 100 & 100 & 100 & 100 & 100 & 100 & 100 & 100 \\
\hline
\end{tabular}

Post- compression Evaluation: [10-12]

\section{Physicochemical characterization of tablets:}

The prepared Rosiglitazone Floating mucoadhesive tablets were studied for their physicochemical properties like weight variation, hardness, thickness, friability and drug content.

\section{A. Weight variation:}

The weight variation test is done by taking 20 tablets randomly and weighed accurately. Not more than two of the individual weight deviates from the average weight by \pm 10 $\%$ and none should deviate by more than twice that percentage. The percent deviation was calculated using the following formula:

$\%$ Deviation $=$ (Individual weight - Average weight / Average weight) X 100

The average weight of tablets in each formulation was calculated and presented with standard deviation.

Table No. 2: Pharmacopoeia specifications for tablet weight variation

\begin{tabular}{|c|c|}
\hline $\begin{array}{c}\text { Average weight of tablets } \\
\text { (mg) }\end{array}$ & $\begin{array}{c}\text { Maximum \% of } \\
\text { difference allowed }\end{array}$ \\
\hline 80 or less & \pm 10 \\
\hline More than 80 but less than 250 & \pm 7.5 \\
\hline 250 or more & \pm 5 \\
\hline
\end{tabular}

\section{B. Tablet Thickness:}

The Thickness and diameter of the tablets from production run is carefully controlled. Thickness can vary with no change in weight due to difference in the density of granulation and the pressure applied to the tablets, as well as the speed of the tablet compression machine. Hence this parameter is essential for consumer acceptance, tablet uniformity and packaging. The thickness and diameter of the tablets was determined using a Digital Vernier caliper. Ten tablets from each formulation were used and average values were calculated. The average thickness for tablet is calculated and presented with standard deviation.

\section{Tablet Hardness:}

Tablet hardness is measured as the force required to break a tablet in a diametric compression test. Tablets require a certain amount of strength, or hardness and resistance to friability, to withstand the mechanical shocks during handling, manufacturing, packaging and shipping. The resistance of the tablet to chipping, abrasion or breakage under condition of storage transformation and handling before usage depends on its hardness. Six tablets were taken from each formulation and hardness was determined using Monsanto hardness tester and the average was calculated. It is expressed in $\mathrm{Kg} / \mathrm{cm}^{2}$.

\section{Friability:}


Tablet hardness is not an absolute indicator of the strength because some formulations when compressed into very hard tablets lose their crown positions. Therefore another measure of the tablet strength, its friability, is often measured. Tablet strength is measured by using Roche friabilator. Test subjects to number of tablets to the combined effect of shock, abrasion by utilizing a plastic chamber which revolves at a speed of $25 \mathrm{rpm}$ for 4 minutes, dropping the tablets to a distance of 6 inches in each revolution.

A sample of pre weighed tablets was placed in Roche friabilator which was then operated for 100 revolutions. The tablets were then de-dusted and reweighed. Percent friability $(\% \mathrm{~F})$ was calculated as

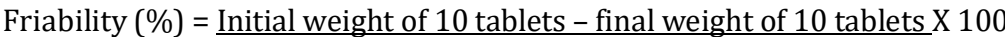 Initial weight of 10 tablets}

Where, $\mathrm{W}_{\mathrm{o}}$ is the initial weight of the tablets before the test and $\mathrm{W}$ is the final weight of the tablets after test.

\section{E. Assay:}

Six tablets of each formulation were taken and amount of drug present in each tablet was determined. Powder equivalent to one tablet was taken and added in $100 \mathrm{~mL}$ of pH 6.8 phosphate buffer followed by stirring for 10 minutes. The solution was filtered through a $0.45 \mu$ membrane filter, diluted suitably and the absorbance of resultant solution was measured by using UV-Visible spectrophotometer at $248 \mathrm{~nm}$ using $\mathrm{pH} 6.8$ phosphate buffer.

\section{In vitro Buoyancy studies:}

The in vitro buoyancy was determined by floating lag time and total floating time. The tablets were placed in a $100 \mathrm{ml}$ beaker containing $0.1 \mathrm{~N} \mathrm{HCL}$. The time required for the tablet to rise to the surface and float was determined as floating lag time (FLT) and duration of time the tablet constantly floats on the dissolution medium was noted as Total Floating Time respectively (TFT).

\section{In vitro release studies: [13-14]}

The drug release rate from Floating mucoadhesive tablets was studied using the USP type II dissolution test apparatus. Tablets were supposed to release the drug from one side only therefore an impermeable backing membrane was placed on the other side of the tablet. The tablet was further fixed to a $2 \times 2 \mathrm{~cm}$ glass slide with a solution of cyanoacrylate adhesive. Then it was placed in the dissolution apparatus. The dissolution medium was $900 \mathrm{ml}$ of $0.1 \mathrm{~N} \mathrm{HCl}$ at $50 \mathrm{rpm}$ at a temperature of $37 \pm 0.5^{\circ} \mathrm{C}$. Samples of $5 \mathrm{~mL}$ were collected at different time intervals up to $12 \mathrm{hrs}$ and analyzed after appropriate dilution by using UV Spectrophotometer at 237, 248, $227 \mathrm{~nm}$

\section{In vitro bioadhesion strength:}

Bioadhesion strength of tablets were evaluated using a microprocessor based on advanced force gauge equipped with a motorized test stand (Ultra Test Tensile strength tester, Mecmesin, West Sussex, UK) according to method describe as it is fitted with $25 \mathrm{~kg}$ load cell, in this test porcine membrane was secured tightly to a circular stainless steel adaptor and the Floating mucoadhesive tablet to be tested was adhered to another cylindrical stainless steel adaptor similar in diameter using a cyanoacrylate bioadhesive. Mucin $100 \mu \mathrm{L}$ of $1 \% \mathrm{w} / \mathrm{v}$ solution was spread over the surface of the mucosa and the tablet immediately brought in contact with the mucosa. At the end of the contact time, upper support was withdrawn at $0.5 \mathrm{~mm} / \mathrm{sec}$ until the tablet was completely detached from the mucosa. The work of adhesion was determined from the area under the force distance curve.
The peak detachment force was maximum force to detach the tablet from the mucosa.

$$
\text { Force of adhesion }=\frac{\text { Bioadhesion strength } \times}{1000} 9.8
$$

$$
\text { Bond strength }=\frac{\text { Force of adhesion }}{\text { Surface area }}
$$

\section{Moisture absorption:}

Agar $(5 \% \mathrm{~m} / \mathrm{V})$ was dissolved in hot water. It was transferred into petridishes and allowed to solidify. Six Floating mucoadhesive tablets from each formulation were placed in a vacuum oven overnight prior to the study to remove moisture, if any, and laminated on one side with a water impermeable backing membrane. They were then placed on the surface of the agar and incubated at $37^{\circ} \mathrm{C}$ for one hour. Then the tablets were removed and weighed and the percentage of moisture absorption was calculated by using following formula:

$\%$ Moisture Absorption $=$ Final weight - Initial weight $\times 100$

\section{Initial weight}

\section{Kinetic analysis of dissolution data: [15-21]}

To analyze the in vitro release data various kinetic models were used to describe the release kinetics.

1. Zero - order kinetic model - Cumulative \% drug released versus time.

2. First - order kinetic model - Log cumulative percent drug remaining versus time.

3. Higuchi's model - Cumulative percent drug released versus square root of time.

4. Korsmeyer equation / Peppa's model - Log cumulative $\%$ drug released versus log time.

\section{In vivo studies - pharmacokinetic studies:}

To investigate the peak plasma concentration pharmacokinetic studies were carried out. The In vivo studies were conducted on Wistar male rats weighing 250$300 \mathrm{gm}$. They were housed in polypropylene cages and had free access to food and water. The dose of rosiglitazone was calculated as per the body weight of animals and developed tablets were formulated considering the calculated dose. The animal protocol was approved by the Animals Ethical Committee. The optimised Floating mucoadhesive matrix tablets were administered orally. Blood samples were collected for over 24 hrs according to a predetermined sample collection schedule. Various pharmacokinetic parameters like C max, T max, AUC were determined. [22] 
RESULT AND DICSUSSION:

Solubility Studies:

Table No. 3: Solubility studies

\begin{tabular}{|c|l|l|}
\hline S.No & Medium & Amount present $(\boldsymbol{\mu g} / \mathbf{m L})$ \\
\hline 1 & Water & 30.67 \\
\hline 2 & Methanol & 100.98 \\
\hline 3 & 0.1 N HCL & 48.82 \\
\hline
\end{tabular}

Drug -Polymer Compatibility Studies by FTIR

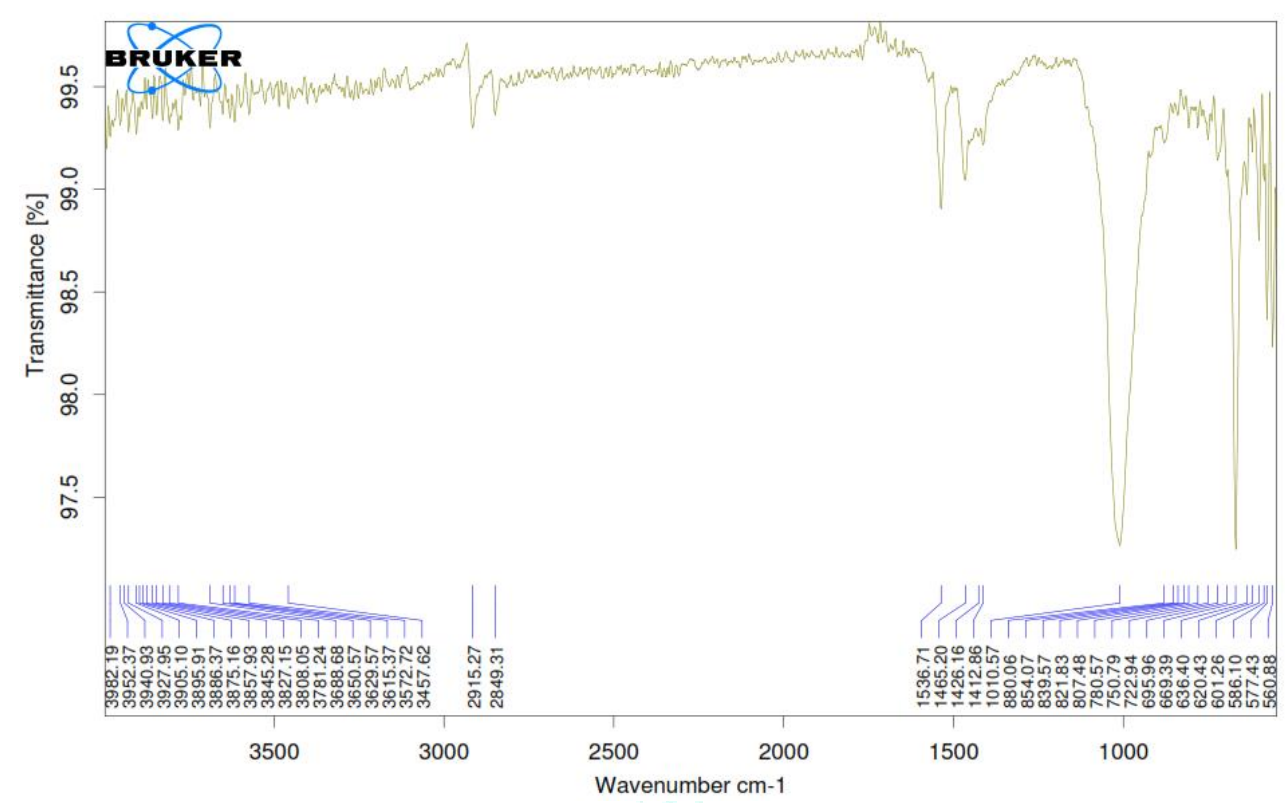

Figure No.1: FTIR of Rosiglitazone pure drug.

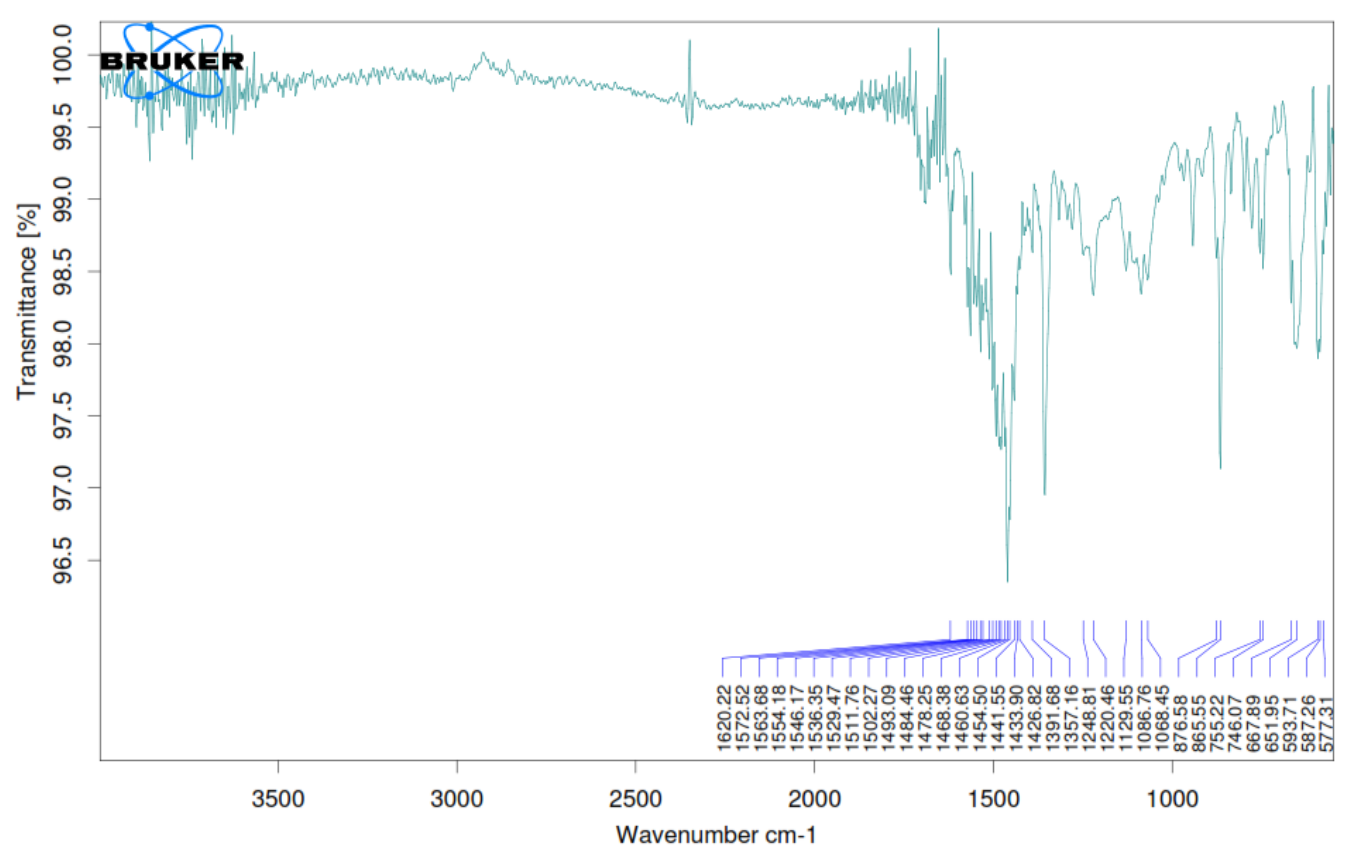

Figure No.2: FTIR Spectra of Optimised Formulation 
Pre-compression Evaluation:

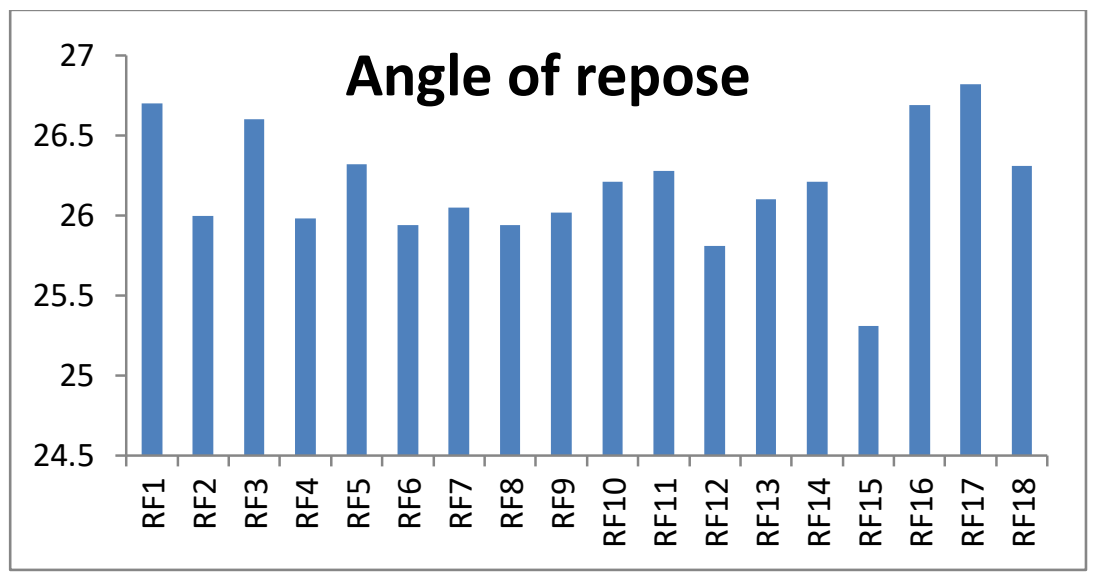

Figure No.3: Angle of Repose for the obtained formulations

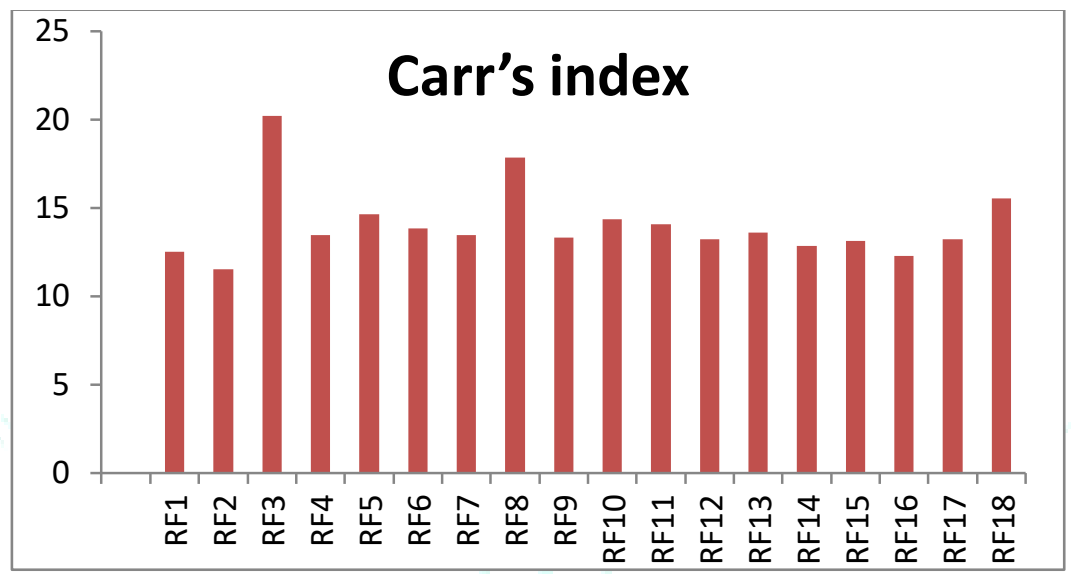

Figure No.4: Carr's Index for the obtained formulations

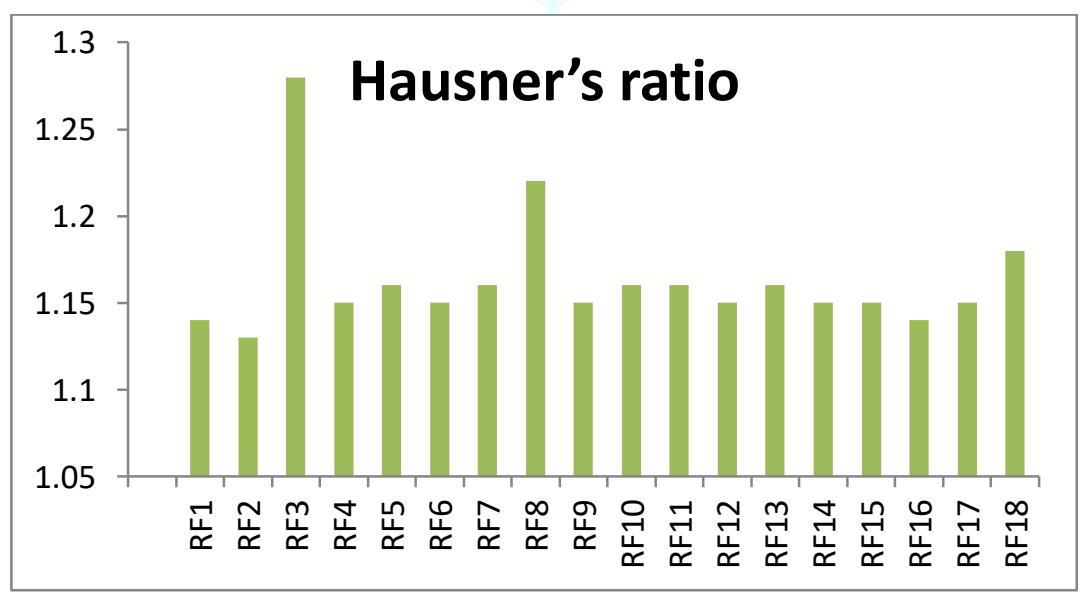

Figure No.5: Hausner's Ratio Index for the obtained formulations 
Post-compression Evaluation:

Table No.4: Evaluation of floating mucoadhesive tablets of Rosiglitazone

\begin{tabular}{|c|c|c|c|c|c|c|c|}
\hline $\begin{array}{l}\text { Formulation } \\
\text { Code }\end{array}$ & $\begin{array}{l}\text { Thickness } \\
\text { (mm) }\end{array}$ & $\begin{array}{c}\text { Average } \\
\text { Weight (mg) }\end{array}$ & $\begin{array}{l}\text { Hardness } \\
\left(\mathrm{Kg} / \mathrm{cm}^{2}\right)\end{array}$ & $\begin{array}{c}\text { Friability } \\
\text { (\%) }\end{array}$ & $\begin{array}{c}\text { Content } \\
\text { uniformity }\end{array}$ & $\begin{array}{l}\text { Total Floating } \\
\text { time (Hours) }\end{array}$ & $\begin{array}{c}\text { Floating Lag } \\
\text { time (Sec) }\end{array}$ \\
\hline RF1 & $4.59 \pm 0.09$ & $98.25 \pm 0.28$ & $5.2 \pm 0.15$ & $0.35 \pm 0.04$ & $95.36 \pm 0.27$ & $>12$ & $35.3 \pm 0.37$ \\
\hline RF2 & $4.91 \pm 0.08$ & $99.35 \pm 0.24$ & $5.6 \pm 0.13$ & $0.29 \pm 0.02$ & $99.25 \pm 0.24$ & $>12$ & $43.0 \pm 0.34$ \\
\hline RF3 & $4.87 \pm 0.04$ & $95.61 \pm 0.19$ & $5.9 \pm 0.19$ & $0.51 \pm 0.06$ & $98.14 \pm 0.21$ & $>12$ & $48.1 \pm 0.36$ \\
\hline RF4 & $4.39 \pm 0.06$ & $99.39 \pm 0.24$ & $5.4 \pm 0.09$ & $0.48 \pm 0.02$ & $100.2 \pm 0.19$ & $>12$ & $39.2 \pm 0.31$ \\
\hline RF5 & $4.99 \pm 0.10$ & $99.48 \pm 0.17$ & $5.8 \pm 0.13$ & $0.63 \pm 0.04$ & $97.45 \pm 0.24$ & $>12$ & $32.9 \pm 0.30$ \\
\hline RF6 & $4.89 \pm 0.08$ & $98.67 \pm 0.39$ & $5.9 \pm 0.17$ & $0.81 \pm 0.09$ & $98.61 \pm 0.30$ & $>12$ & $25.6 \pm 0.29$ \\
\hline RF7 & $4.68 \pm 0.04$ & $97.52 \pm 0.25$ & $5.0 \pm 0.20$ & $0.23 \pm 0.08$ & $99.75 \pm 0.29$ & $>12$ & $12.0 \pm 0.28$ \\
\hline RF8 & $4.90 \pm 0.11$ & $98.15 \pm 0.20$ & $5.3 \pm 0.17$ & $0.28 \pm 0.05$ & $99.87 \pm 0.34$ & $>12$ & $15.7 \pm 0.24$ \\
\hline RF9 & $4.19 \pm 0.06$ & $99.45 \pm 0.26$ & $5.7 \pm 0.18$ & $0.61 \pm 0.10$ & $96.10 \pm 0.18$ & $>12$ & $17.0 \pm 0.23$ \\
\hline RF10 & $4.72 \pm 0.02$ & $100.0 \pm 0.17$ & $5.9 \pm 0.16$ & $0.38 \pm 0.05$ & $99.38 \pm 0.24$ & $>12$ & $39.2 \pm 0.18$ \\
\hline RF11 & $4.68 \pm 0.08$ & $98.31 \pm 0.16$ & $5.4 \pm 0.15$ & $0.47 \pm 0.07$ & $97.82 \pm 0.18$ & $>12$ & $45.6 \pm 0.25$ \\
\hline RF12 & $4.39 \pm 0.03$ & $97.45 \pm 0.31$ & $5.1 \pm 0.24$ & $0.59 \pm 0.11$ & $99.34 \pm 0.19$ & $>12$ & $110.0 \pm 0.17$ \\
\hline RF13 & $4.57 \pm 0.15$ & $99.12 \pm 0.19$ & $5.3 \pm 0.17$ & $0.67 \pm 0.08$ & $96.92 \pm 0.35$ & $>12$ & $45.0 \pm 0.19$ \\
\hline RF14 & $4.38 \pm 0.06$ & $97.35 \pm 0.24$ & $5.8 \pm 0.24$ & $0.15 \pm 0.04$ & $97.24 \pm 0.27$ & $>12$ & $55.2 \pm 0.25$ \\
\hline RF15 & $4.29 \pm 0.01$ & $98.46 \pm 0.21$ & $5.1 \pm 0.26$ & $0.43 \pm 0.09$ & $95.89 \pm 0.26$ & $>12$ & $51.0 \pm 0.26$ \\
\hline RF16 & $4.35 \pm 0.08$ & $99.14 \pm 0.23$ & $5.0 \pm 0.28$ & $0.57 \pm 0.12$ & $99.75 \pm 0.29$ & $>12$ & $70.8 \pm 0.19$ \\
\hline RF17 & $4.62 \pm 0.10$ & $97.32 \pm 0.21$ & $5.9 \pm 0.21$ & $0.43 \pm 0.05$ & $97.19 \pm 0.30$ & $>12$ & $74.6 \pm 0.30$ \\
\hline RF18 & $4.64 \pm 0.15$ & $99.47 \pm 0.20$ & $5.7 \pm 0.15$ & $0.37 \pm 0.09$ & $98.69 \pm 0.21$ & $>12$ & $130 \pm 0.38$ \\
\hline
\end{tabular}

In vitro release studies:

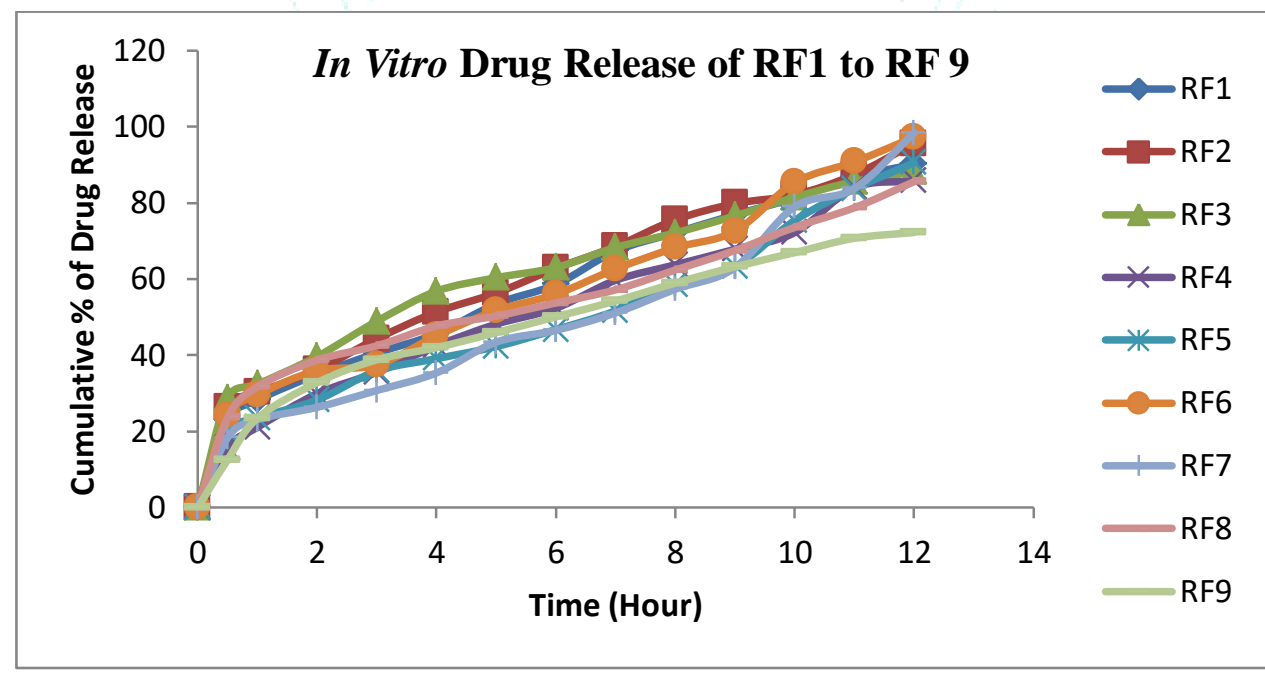

Figure No.6: In vitro Dissolution study of RF 1 to RF 9

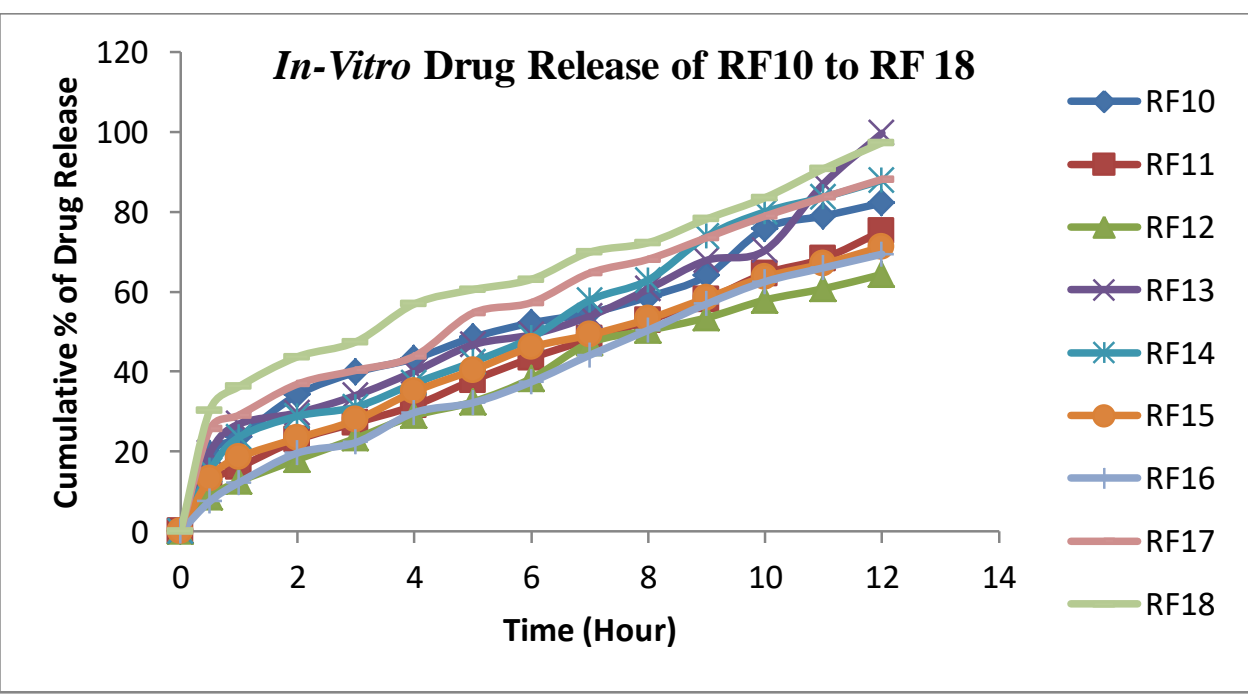

Figure No.7: In vitro Dissolution study of RF 10 to RF 18 
Moisture absorption, bioadhesion strength values of selected formulations

Table No. 5: Moisture absorption, bioadhesion strength values of selected formulations.

\begin{tabular}{|c|c|c|c|}
\hline \multirow{2}{*}{$\begin{array}{c}\text { Formulation } \\
\text { Code }\end{array}$} & Moisture absorption & \multicolumn{2}{|c|}{ Bioadhesion strength } \\
\cline { 3 - 4 } & & $\begin{array}{c}\text { Peak } \\
\text { detachment } \\
\text { force (N) }\end{array}$ & $\begin{array}{c}\text { Work of } \\
\text { adhesion } \\
\text { (mJ) }\end{array}$ \\
\hline RF13 & $66 \pm 0.33$ & $4.8 \pm 0.12$ & $23.41 \pm 6.18$ \\
\hline
\end{tabular}

Each value represents the mean \pm SD $(n=3)$

\section{Release kinetics:}

Data of in vitro release studies of formulations which were showing better drug release were fit into different equations to explain the release kinetics of Rosiglitazone release from mucoadhesive tablets. The data was fitted into various kinetic models such as zero, first order kinetics, higuchi and korsmeyer peppas mechanisms and the results were shown in below table.

Table No 6: Table of release kinetics and correlation factors

\begin{tabular}{|c|c|c|c|c|c|c|c|c|c|c|c|c|}
\hline 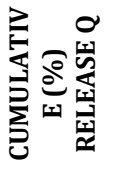 & $\underbrace{E}_{\sum^{M}}$ & $\begin{array}{l}E \\
5 \\
0 \\
\approx\end{array}$ & 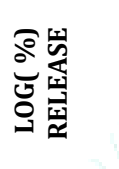 & 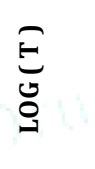 & 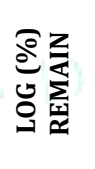 & 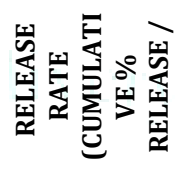 & 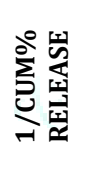 & 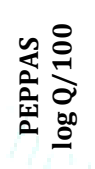 & 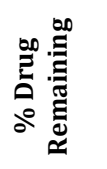 & $\frac{n}{\sigma}$ & $\stackrel{n}{\partial}$ & $\begin{array}{l}\dot{2}= \\
\dot{\partial}=\vec{\sigma}\end{array}$ \\
\hline 0 & 0 & 0 & & & 2.000 & & & & 100 & 4.642 & 4.642 & 0.000 \\
\hline 19.7 & 0.5 & 0.707 & 1.294 & -0.301 & 1.905 & 39.400 & 0.0508 & -0.706 & 80.3 & 4.642 & 4.314 & 0.327 \\
\hline 26.92 & 1 & 1.000 & 1.430 & 0.000 & 1.864 & 26.920 & 0.0371 & -0.570 & 73.08 & 4.642 & 4.181 & 0.461 \\
\hline 29.7 & 2 & 1.414 & 1.473 & 0.301 & 1.847 & 14.850 & 0.0337 & -0.527 & 70.3 & 4.642 & 4.127 & 0.514 \\
\hline 34.06 & 3 & 1.732 & 1.532 & 0.477 & 1.819 & 11.353 & 0.0294 & -0.468 & 65.94 & 4.642 & 4.040 & 0.602 \\
\hline 40.04 & 4 & 2.000 & 1.602 & 0.602 & 1.778 & 10.010 & 0.0250 & -0.398 & 59.96 & 4.642 & 3.914 & 0.728 \\
\hline 46.72 & 5 & 2.236 & 1.670 & 0.699 & 1.727 & 9.344 & 0.0214 & -0.330 & 53.28 & 4.642 & 3.763 & 0.879 \\
\hline 49.25 & 6 & 2.449 & 1.692 & 0.778 & 1.705 & 8.208 & 0.0203 & -0.308 & 50.75 & 4.642 & 3.702 & 0.939 \\
\hline 53.86 & 7 & 2.646 & 1.731 & 0.845 & 1.664 & 7.694 & 0.0186 & -0.269 & 46.14 & 4.642 & 3.587 & 1.055 \\
\hline 60.64 & 8 & 2.828 & 1.783 & 0.903 & 1.595 & 7.580 & 0.0165 & -0.217 & 39.36 & 4.642 & 3.402 & 1.240 \\
\hline 67.85 & 9 & 3.000 & 1.832 & 0.954 & 1.507 & 7.539 & 0.0147 & -0.168 & 32.15 & 4.642 & 3.180 & 1.462 \\
\hline 70.34 & 10 & 3.162 & 1.847 & 1.000 & 1.472 & 7.034 & 0.0142 & -0.153 & 29.66 & 4.642 & 3.095 & 1.546 \\
\hline 86.95 & 11 & 3.317 & 1.939 & 1.041 & 1.116 & 7.905 & 0.0115 & -0.061 & 13.05 & 4.642 & 2.354 & 2.287 \\
\hline 99.64 & 12 & 3.464 & 1.998 & 1.079 & -0.444 & 8.303 & 0.0100 & -0.002 & 0.36 & 4.642 & 0.711 & 3.930 \\
\hline
\end{tabular}

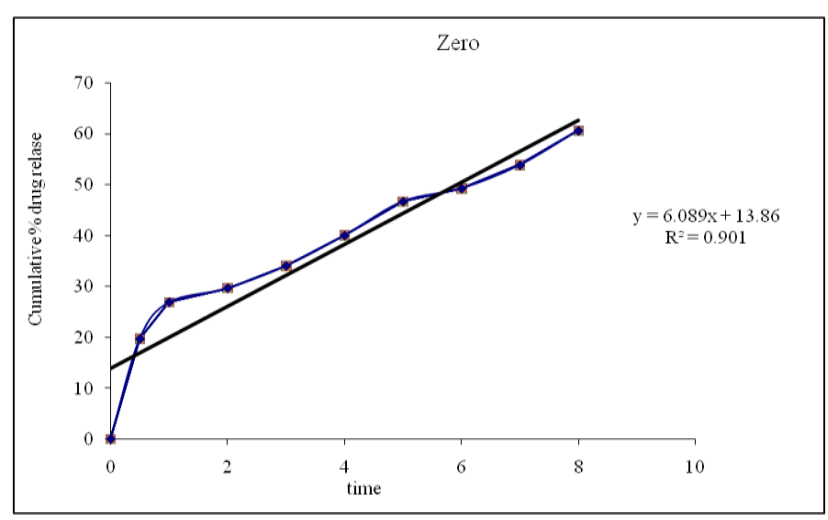

Figure No.8: Zero order plot of optimized formulation

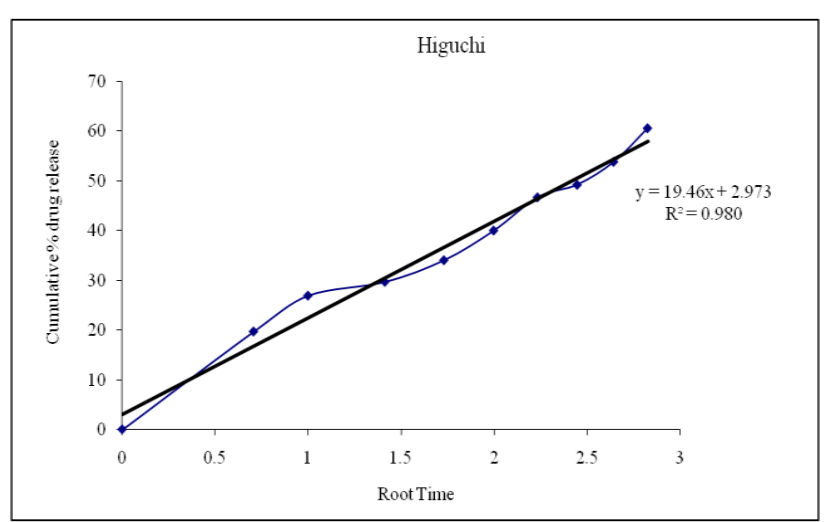

Figure No.9: Higuchi plot of optimized formulation 


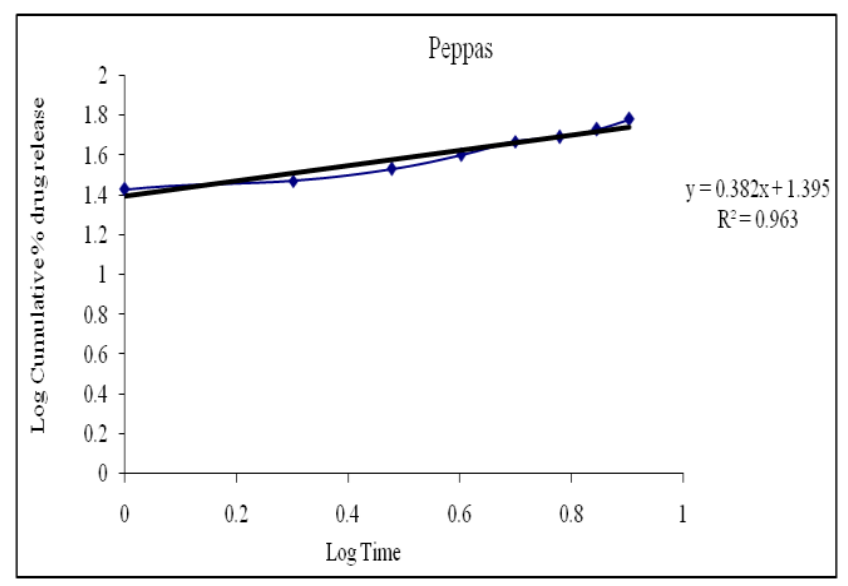

Figure No.10: Koresmeyer-peppas plot of optimized formulation

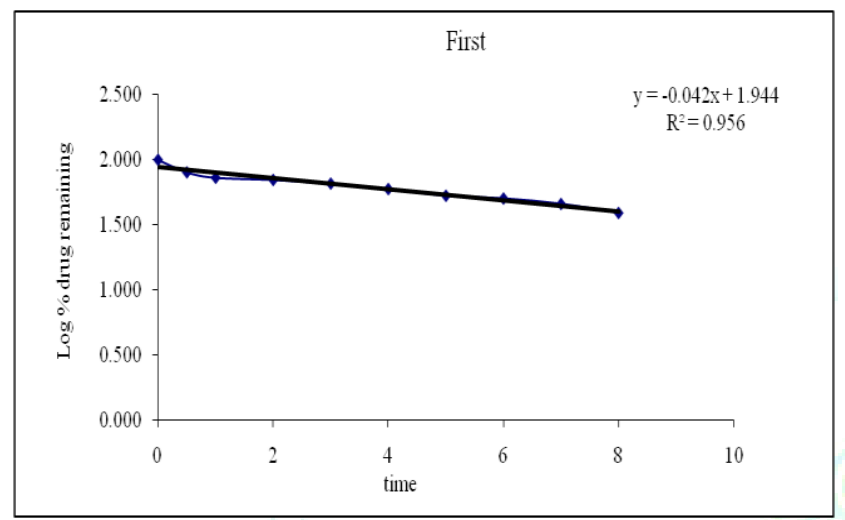

Figure No.11: First order plot of optimized formulation

Based on the all studies RF13 formulation was found to be better when compared with all other formulations. This formulation was following Higuchi mechanism with regression value of 0.980 .

\section{In vivo Studies - Pharmacokinetic Studies:}

All the pharmacokinetics parameters displayed in Table. Mean time to reach peak drug concentration ( $\mathrm{T}_{\max }$ ) was 1.75 hours, while mean maximum drug concentration (Cmax) was $640 \mathrm{mg} / \mathrm{mL}$. The values for $\mathrm{C}_{\max }, \mathrm{T}_{\max }$, AUC were found to be comparable indicating that their sustained release patterns were similar.

Table No 7: Pharmacokinetic parameters of optimized formulation

\begin{tabular}{|c|c|c|}
\hline S.No & Parameter & Rosiglitazone \\
\hline 1 & $\mathrm{C}_{\max }$ & $640 \mathrm{mg} / \mathrm{mL}( \pm 0.22)$ \\
\hline 2 & $\mathrm{~T}_{\max }(\mathrm{hr})$ & $1.75 \mathrm{hours}( \pm 0.56)$ \\
\hline 3 & AUC & $3.62 \mathrm{mg} / \mathrm{L} \cdot \mathrm{h}( \pm 1.24)$ \\
\hline
\end{tabular}

The solubility studies indicated that the drug is having less solubility in water as compared to methanol and $0.1 \mathrm{~N} \mathrm{HCl}$. The solubility data confirms that rosiglitazone is one of the best model drug to be formulated as GRDDS. The FTIR studies indicated that the drug and polymers have no interaction. There was no change is the basic drug peaks. The angle of repose of all the formulations is under 30 degree. Hence we can say that the powder blend has a good flow property. The Carr's Index and Hausner ratio results also predict that the powder blend has a good flow property. So direct compression technique can be used to formulate the tablets. The mean thickness of all the formulations ranges between 4.19 to $4.99 \mathrm{~mm}$. It can be concluded that all the tablets have uniform size and shape. The weight of the tablets ranged between $95.61 \mathrm{mg}$ to $100 \mathrm{mg}$. The maximum weight variation limit is \pm 7.5 for tablets ranging $80 \mathrm{mg}$ to $250 \mathrm{mg}$. So the prepared tablets were within the prescribed range. The hardness of the tablets ranged from $5-6 \mathrm{Kg} / \mathrm{cm}^{2}$. The friability test shows that all the tablets have friability below 1 . This suggests that the tablets prepared had a good mechanical strength and resistance. All the formulations have good drug content. The floating lag time of the tablets was lowest for RF7 $12 \mathrm{sec}$ and highest for RF18 130sec. The in-vitro drug release was performed using $0.1 \mathrm{~N} \mathrm{HCl}$ at $\mathrm{pH} 1.2$ for $12 \mathrm{hrs}$. The results indicate that the lowest drug release was for formulation RF12 which contains high concentration of Karaya Gum. The highest drug release is found in formulation RF13 which contains chitosan. There is a significant decrease in the drug release rate with increase proportion of karaya gum. The formulations containing carbopol and chitosan showed a uniformity in drug release. The bioadhesion strength of RF13 was found to be optimum to satisfy the need of mucoadhesion for prolonged period of time. Various kinetics study were performed and it was found that RF13 formulation was found to be better when compared with all other formulations. This formulation was following Higuchi mechanism with regression value of 0.980 . The in-vivo pharmacokinetics studies showed that the drug reaches the maximum concentration in $1.75 \mathrm{hr}$. The $\mathrm{C}_{\max }$ and AUC data predicts that the drug has a good oral bioavailabilty.

\section{CONCLUSION}

Form the obtained results, it can be concluded that the drugs can be easily formulated as GRDDS using different ratios of rate controlling polymers like chitosan, NaCMC, HPMC K200 and Carbopol 934. Chitosan is found to be promising polymer in controlling the rate and extent of drug release from the dosage form. Further work can be carried out to design more GRDDS.

\section{ACKNOWLEDGEMENT}

The authors would like to express sincere gratitude to Vikas College of Pharmaceutical Sciences and Bengal School of Technology for their esteemed support towards this work.

\section{AUTHORS CONTRIBUTION}

All the authors have equal contribution in making this research a success.

\section{CONFLICT OF INTEREST}

Declared None.

\section{REFERENCES}

1. Siraj S, Khurshid MI. Current Trends in Gastroretentive FloatingBioadhesive Drug Delivery System. 25 April 2016.

2. Rouge N, Buri P, Doelker E, Drug absorption sites in the gastrointestinal tract and dosage forms for site specific. Delivery, Int. J. Pharm. 136 (1996) 117-139

3. Streube A, Siepmann J, Bodmeier R, Drug delivery to the upper small intestine window using gastro retentive technologies, Current Opinion in Pharmacology 2006, 6:501-508.

4. Prajapati VD, Raft forming system An upcoming approach of gastroretentive drug delivery system, Journal of Controlled Release 168 (2013) 151-165.

5. Bardonnet PL , Faivre V, Pugh WJ , Piffaretti JC, Falson F . Gastro retentive dosage forms: Overview and special case of Helicobacter pylori Journal of Controlled Release 111 (2006) 1 18.

6. Eswer G, Saritha M, Formulation and Evaluation of Atenolol Floating Tablets Using Different Polymers:Guargum, Sodium 
Alginate, Hpmc100cps and Carbopol940, International Journal of Pharmaceutical \& Biological Archives 2011; 2(4):1146-1151.

7. Someshwar K, Kalyani, Chithaluru K, Ramarao T, Kumar K, Formulation and evaluation of effervescent floating tablets of tizanidine hydrochloride, Acta Pharm. 61 (2011) 217-226.

8. Pattanayak D, Adepu R, Das S, Sura RS , A systemic review on Floating mucoadhesive drug delivery system, IAJPS 2018, 05 (04), 2970-2978.

9. Banker GS, Rhodes CT. Modern Pharmaceutics. Sustained and Controlled Release Delivery Systems. Marcel Dekker. 2002; $4^{\text {th }}$ :501-528.

10. Peddapalli H, Bakshi V, Boggula N, Formulation, in vitro and ex vivo characterization of mucoadhesive buccal tablets for antihypertensive drug, Asian J Pharm Clin Res, Vol 11, Issue 8, 2018, 402-411.

11. Hemnani M, Patel P, Patel G, Daslaniya D, Shah A, Matrix Tablets: A Tool of Controlled Drug Delivery, American Journal of Pharmatech Research. 1(4); 2249-3387:2011.

12. Sahel M, Al-Saidan, Krishnaiah YSR, Satyanarayana V. In-Vitro And In-Vivo Evaluation Of Guargum Matrix Tablets For Oral Controlled Release Of Water-Soluble Diltiazem Hydrochloride. AAPS Pharm. Sci.Tech. 6(1) ; 31-36:2005.

13. Das S, Pattanayak D , Formulation and optimization of gastro retentive drug delivery system containing Glipizide, , International Journal of Pharmacy and Pharmaceutical Sciences, ; Vol 4, Issue 1, 2012, 203-205.
14. Alhamdany AT, Abbas AAK, formulation and In vitro evaluation of Amlodipine gastroretentive floating tablets using a combination of hydrophilic and hydrophobic polymers, Int J App Pharm, Vol 10, Issue 6, 2018, 126-134.

15. Nokhodchi A, Raja S, Patel P, Asare-Addo K, The Role Of Oral Controlled Release Matrix Tablets In Drug Delivery Systems, Bioimpacts. 2(4);175-187:2012.

16. Vyas SP, Khar RK. Controlled Drug Delivery Concepts and Advances. CBS Publishers, 2001;1st:1-53.

17. Siegel RA, Rathbone MJ, Departments of Pharmaceutics and Biomedical Engineering: Chapter 2: Overview of Controlled release mechanisms, Minnepolis. 2012:19-43.

18. Bramhanker DM, Jaiswal SB, Controlled Release Medications, Biopharmaceutics And Pharmacokinetics a Treatise. Vallabh Prakashan, 1995; $2^{\text {nd }}$ :335-375.

19. Peppas NA. Analysis of Fickian And Non-Fickian Drug Release From Polymers. Pharm.Acta.Helv. 60(4);110-111:1985.

20. Korsmeyer RW, Gurny R, Doelker E, Peppas NA, Mechanism of Solute Release From Porous Hydrophilic Polymers. Int. J. Pharm. 15;25-35:1983.

21. Hixon AW, Crowell JH, Dependence of Reaction Velocity Upon Surface and Agitation,I- Theoretical Consideration. Ind. Eng. Chem. 23;923-931:1931.

22. Shin JW, Seol IC, Son CG, Interpretation of animal dose and human equivalent dose for drug development, The Journal of Korean Oriental Medicine 2010;31(3):1-7 